\title{
Michel de Certeau
}

The Mystic Fable: The Sixteenth and Seventeenth Centuries. Edited by Luce Giard and translated by Daniel Smith. Chicago: University of Chicago Press, 2015.

Pp. Xvi $+287 . \mathrm{Hb}, \$ 45$.

Jesuit Michel de Certeau avowed that among all his writings The Mystic Fable: The Sixteenth and Seventeenth Centuries was the most personal and consequential. There came with the publication of the first volume in 1982 the promise of a second. Appearing in 2013 under the care of editor and executrix Luce Giard, the sequel resembles a fractured mirror. No matter where we gloss or gaze upon it we glimpse shards of ourselves. Mystical in character, the writing is at once illuminating and opaque, terse and telling, lucid and visionary, inventive and erudite, ludic and serious.

The flyleaves of the English editions of both volumes illustrate details from Hieronymous Bosch's Garden of Earthly Delights. Suggesting that what lies between the covers is a hortus voluptatis, an unimaginably delightful delirium, the details from dexter panel indicate that the composition of The Mystic Fable is mosaic and that its truth is in shadows and shatters. Like the eyes of the painting that stare at the viewer who beholds it in the Prado, the voice of the author seems to ask us, "What do you say about who you are in believing you're telling me who I am? (Michel de Certeau, "Un lieu pour se perdre," in La Fable mystique: XVIe-XVIIe siècle [Paris: Éditions Gallimard, 1982], 99). In composition and style both volumes of The Mystic Fable embody a mystical relation with what they study and, for reason of the circumstances of its publication, the chapters tend to be luminous diffractions of each other.

Luce Giard follows that plan that de Certeau had conveyed to her shortly before his death. Reviewing de Certeau's correspondence and comparing the manuscripts and published articles he wished to set in contiguity, she places at the beginning a chapter on the gaze that marks Nicolas of Cusa's peripatetic life and works. De icona becomes "the mirror of its readers. It presents them with an object in keeping with what they expect or believe of it" (67). Revealing how an irrational and even mad character of things makes reason possible, Cusa's ocular writings become emblems of mystical experience. The chapters that follow vary on how Cusa's gaze becomes "his own surprise," and that what "he 'sees"' (70), unalterably his own folly, becomes a window onto an originary confusion that prompts us to believe in the world before our eyes. In chapters two, three, and four Saint John of the Cross and the mystics to whom he is compared are poets who invent space through creative doubt. "A form and a force of saying" (89) coincide: Saint John's Dichos (1578-82) turn words into “a living forest of voices" (92) [une forêt vivante de voix (155)], what de Certeau 
calls a "space of freedom" (94). Such too is the effect of his fragmentary Correspondance in which spiritual experience is found in the "other," or the welcome alterity of a discourse accessible to one and all. In compositions that include both poetry and commentary, the writings inaugurate a space "between," a space in which, vectored, sens becomes meaning when "mystic words" (117) are felt in passage and movement.

In the fifth chapter, de Certeau notes how, at the threshold of the first scientific revolution mystical discourse affirms and brackets secular foundations of truth. Congruent with Merleau-Ponty's concept of perceptual faith, "an expectation that structures all perception" (124), "meaning" becomes a field of play that moves between what is anticipated and what resists being named. He then engages plural ways of thinking, doing and writing, what he calls manières de faire. In chapter six, stories of passion that belong to the mystical canon emphasize how a fluid relation or fusion of subject and object prevails over enlightened reason. Chapter seven, taking up incarceration, travel, and illumination in Jean-Joseph Surin's Science expérimentale des choses de l'audelà (1663, reprinted in Triomphe de l'amour divin sur les puissances de l'enfer, ed. Jacques Prunaire [Grenoble: Jérôme Millon, 1980]) studies how an autobiographical tale of voyage engages alterity in the narrative splitting the "I" of "here" and the "he" of "then." Things extraordinary and ordinary converge when duration replaces chronological time. A "world of trivial, banal, obvious details passes into the sphere of the strange" (248). As in psychoanalysis, Surin's mystical voyage is drawn through descriptions of his body, a site and process where the fantastic (and deeply religious) register of everyday life is written.

Chapter eight, "Angelic Speech," inquires of the status of angels: are they fairies or heralds? Where they belong in the order of things? When in history are they manifest? The angel is a strange being, a wisp "that knows," that hovers about us, that refuses to "say what it means." For Klee, Artaud, and Benjamin, the angel becomes an event of cognition: related to an angle, it flutters at the threshold of visual and aural perception. Jacob Boehm locates the angel in a "metaphysics of spiritual language" while Angelus Silesius (Johannes Scheffler) tracks its passage in the distance it draws between subjects and objects. An image that contradicts or mediates historical time, the angel becomes an ineffable messenger of mystical words. Chapter nine, titled "Biblical Erudition," studies how (much as in today's political arena) the Bible had become a foil to what were considered corrupt institutions: by way of commentary and translation, a "return" to the constitutional character of the Bible, to the spirit of its letter, could hold in place an ideology of faith. Hence Le Maistre de Sacy, whose project of translation extended over the years $1665^{-84}$, aimed at grasp- 
ing the "sense" of the Bible's author. For Sacy translation was a "way of doing" whose mission involved navigating "between lights and shadows, working on the transparency of the message" without losing sight of its author's obscure traces (188). By contrast, for Richard Simon the text was what produced its meaning, and thus erudition, or work written along the margins or borders allowed readers to discern the ineffable presence of God.

In chapter ten, "The Strange Secret: Pascal," the Pensées are shown embracing myriad ways or manners of writing, doing, and speaking. For Pascal different ploys and modes of discourse "multiply possibilities, put things into movement, cause them to turn and return to their unstable equilibria," attesting thus to the "mobile rigor of a style" (196). A close reading of the fourth letter too focuses on what for Pascal was "this strange secret into which God has withdrawn, impenetrable to humans," in other words, "a great lesson for us, far from the sight of humans themselves, to bear in solitude. He has remained hidden under the veil of nature that covers us as far as the Incarnation; and when he had to appear, he further concealed himself in being veiled from humanity" (OEuvres complètes, éd. Louis Lafuma, vol. 6 [Paris : Éditions du Seuil, 1963], 87-90). The mobility of Pascal's style becomes a process of concealment. The deus absconditus is perceived only in movement, in a "manner of thinking that produces as its effect a 'lost God' and a truth that 'wanders [erre] unknown among men'" (218). Mystic in character, Pascal's "discourse shows what it asserts to be invisible" (210).

The book ends on an unnumbered chapter, "The Opera of Speech: Glossalia," an open-ended conclusion that considers how inchoate speech is comparable to mystic fabulation. An intermediate voice, like that of a child learning to speak, babble cannot be pigeonholed. The sound of ecstasy or possession, it can be an audition of verbal fragments, of strange idioms, signs, and sounds packing ordinary conversation, that seem to address no one in particular: a dull murmur, a stuttering, an interruption, an unlikely syncopation, in short, a babble becomes what is indiscernibly other. "What utopia is to social space, glossalia is to oral communication, in circumscribing in a linguistic simulacrum everything else that that the voice realizes besides language when it speaks the language" (215).

Generally known as a cultural critic in his Practice of Everyday Life, Michel de Certeau is first and foremost a historian and anthropologist of belief. His writings on mystical process and historiography tend to be overlooked, perhaps because the religious grounding of life has been severely repressed or, simply, because editors feel that publishing works on religion make for poor returns on their investments. The University of Chicago Press can be con- 
gratulated for thinking otherwise. Recovering a deeply embedded process he situates on the eve of modern times, de Certeau reminds us that mystics and mystical things are a vital part of our lives. In Daniel Smith's nimble and deft translation, along with Luce Giard's limpid introduction and exhaustive index, this second volume of The Mystic Fable is not only a stunning piece of history and theory but, from another angle, a background informing what Benjamin Perec called a "user's guide" to the art of living.

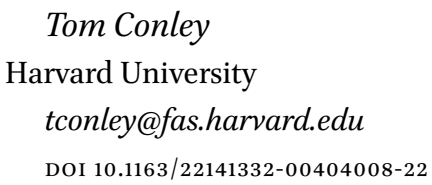

